Dhaka Univ. J. Biol. Sci. 25(1): 75-81, 2016 (January)

\title{
ACCUMUlATION OF Zn, Cu, Fe, Mn AND Pb DUE TO BRICK MANUFACTURING IN AGRICULTUTRAL SOILS AND PLANTS
}

\author{
Abdul Halim Farhad Sikder, Sayma Khanom, Md. Faruque Hossain ${ }^{1}$ \\ AND ZAKIA PARVEEN* \\ Department of Soil, Water and Environment, University of Dhaka, Dhaka 1000, Bangladesh
}

Key words: Accumulation, Brick kiln, Micronutrient, Heavy metal contamination

\begin{abstract}
Experiment was carried out to assess the concentration of $\mathrm{Zn}, \mathrm{Cu}, \mathrm{Pb}, \mathrm{Fe}$ and $\mathrm{Mn}$ in agricultural soil and plant near selected brick kilns. Soils and plants samples were collected from four points such as 250, 500, 1000 and 1500 m away from brick kilns. Three metals were found at elevated levels in the soils near brick kilns such as, $\mathrm{Pb}$ (92.5 to $214 \mathrm{mg} / \mathrm{kg}$ ), Zn (86 to $156 \mathrm{mg} / \mathrm{kg}$ ) and $\mathrm{Cu}$ (24.7 to $46.9 \mathrm{mg} / \mathrm{kg}$ ). It may be caused due to burning of poor quality coal and fire woods. The uptake of heavy metals in the nearest areas $(250 \mathrm{~m})$ of the brick kilns was significantly higher than the areas far from the brick production and their concentrations range from 7 to $543 \mathrm{mg} / \mathrm{kg}$ for $\mathrm{Pb}, 23$ to $101 \mathrm{mg} / \mathrm{kg}$ for $\mathrm{Zn}, 10$ to 41 $\mathrm{mg} / \mathrm{kg}$ for $\mathrm{Cu}, 35$ to $1309 \mathrm{mg} / \mathrm{kg}$ for Fe and 26 to $126 \mathrm{mg} / \mathrm{kg}$ for Mn. Results indicated that soils and plants accumulated maximum amount of micronutrients within 500 to $1000 \mathrm{~m}$ distance from brick kilns significantly decreased with distance. Iron and manganese were not polluting the soils near brick kilns but affecting the plants. Therefore, it can be suggested that no agricultural crops should be grown within $1000 \mathrm{~m}$ distance from a brick kiln.
\end{abstract}

\section{Introduction}

With 160 million population ${ }^{(1)}$ and rapid urbanization Bangladesh is an area of booming construction industry. To facilitate this 8.6 billion bricks are needed per year(2). These bricks are produced by 6000 authorized and thousands of unauthorized brick kilns across the country ${ }^{(3)}$.

Brick kilns are well known as one of the most important sources of air pollutant. They emit a variety of greenhouse gases and heavy metals during the production of brick. Among them $\mathrm{Pb}, \mathrm{Hg}, \mathrm{Zn}, \mathrm{Cu}, \mathrm{Ni}, \mathrm{Se}, \mathrm{Fe}$ and $\mathrm{Cd}$ are the most common ones ${ }^{(4)}$. The major reason for emitting these gases is improper burning of coal and wood ${ }^{(5)}$, besides these fly ash is an important polluting agent which contains high concentration of $\mathrm{Na}, \mathrm{K}, \mathrm{Zn}, \mathrm{Mg}$ and $\mathrm{Fe}$ as well as a wide range of heavy metals such as $\mathrm{Hg}, \mathrm{Pb}, \mathrm{Cd}$ and $\mathrm{Zn}$ and non ferrous metals ${ }^{(6)}$.

*Author for correspondence: <zakiaparveen1@yahoo.ca>. ${ }^{1}$ American International UniversityBangladesh, Kemal Ataturk Avenue, H 58/B, Rd 21, Banani, Dhaka 1213, Bangladesh. 
Heavy metal and fly ash both fall down to soil due to gravity after emission. This fall down is also dependent on wind direction, speed, humidity, season of a year etc. When the heavy metals move down to the soil, they mix up with soil and degrade it. Besides some heavy metals may be lossed by leaching through soil and ultimately pollute the groundwater.

Soils near brick kilns are relatively acidic in nature and brick kilns emit a large amount of $\mathrm{SO}_{2}$. This greenhouse gas lowers the $\mathrm{pH}$ of the adjacent soil when it is mixed up with water and produce $\mathrm{H}_{2} \mathrm{SO}_{4}$. At low $\mathrm{pH}$, heavy metals create bonds with other ions ${ }^{(7)}$. At high $\mathrm{pH}$, these metals tend to be precipitate and soil $\mathrm{pH}$ also controlling the solubility of metal hydroxides, carbonates and phosphates, hydrolysis, ion-pair formation, organic matter solubility, as well as the surface charge of iron and aluminum oxides and clay edges ${ }^{(8)}$. Mobility of heavy metals in soils is driven by three major factors such as specific adsorption to different solid phases, precipitation of sparingly soluble compounds and the formation of relatively stable complexes or chelates with the soil organic matter(9). Besides these mineral grain size and organic matter play a vital role in metal accumulation in the top soil by forming chelates ${ }^{(10)}$.

A large amount of toxic elements are produced continuously from brick kilns but a scanty report is available on heavy metal contamination due to brick production. The objective of the present experiment was to find out the concentration of some heavy metals $(\mathrm{Zn}, \mathrm{Cu}, \mathrm{Fe}, \mathrm{Mn}$ and $\mathrm{Pb})$ in soil and plants due to the establishment of brick kilns.

\section{Materials and Methods}

Sites were selected on the basis of soil parent material, cropping pattern and wind direction from the brick kiln to the field. Three sites were located in three different districts such as, Mawna (Gazipur), Kalampur (Dhaka) and Noyadingi (Manikganj).

Both soil and plant samples (rice and maize straws, \pm 100 days old) were taken from the agricultural fields adjacent to the brick kilns in February, 2014. Four distances were chosen. These were 250, 500, 1000 and $1500 \mathrm{~m}$ from brick kilns. Three replicate samples $(0$ - $15 \mathrm{~cm}$ depth) were collected and mixed thoroughly to make a composite sample. A composite plant (rice and maize straws) samples were collected from the respective field by uprooting 12 plant samples from each point. Soil samples were air-dried, ground by wooden hammer and sieved through stainless steel sieve $(2 \mathrm{~mm})$ and preserved for analysis. Plant samples were dried and powdered in a mechanical grinder ( $0.5 \mathrm{~mm}$ sieve) and kept in polyethylene bags for chemical analysis.

The same floodplain parent material of all three sites was selected from the same physio-graphy such as, Young Brahmaputra and Jamuna Floodplain. Young Brahmaputra and Jamuna Floodplain soils are traditionally low in organic carbon (OC) and $\mathrm{CEC}^{(11)}$. The variation of OC may occur due to extensive agricultural practice. Soils 
are mainly acidic in nature may be due to the application of excess urea fertilizer. Some chemical properties of the soils are presented in Table 1.

Table 1. Some chemical properties of Mawna, Noyadingi and Kalampur soils.

\begin{tabular}{llllll}
\hline & & \multicolumn{4}{c}{ Sampling distances from brick kiln $(\mathrm{m})$} \\
\hline Sampling sites & Properties & 250 & 500 & 1000 & 1500 \\
\hline Mawna & $\mathrm{pH}$ & 5.11 & 5.23 & 5.54 & 5.60 \\
& CEC (me/100 g ) & 1.12 & 1.02 & 0.89 & 0.81 \\
& Organic Carbon (\%) & 0.61 & 0.87 & 0.90 & 1.19 \\
& Clay (\%) & 9.20 & 8.70 & 11.2 & 10.7 \\
\multirow{5}{*}{ Noyadingi } & $\mathrm{pH}$ & 5.22 & 6.14 & 6.62 & 7.4 \\
& CEC (me/100 g ) & 1.14 & 1.10 & 1.17 & 1.08 \\
& Organic carbon (\%) & 1.14 & 1.19 & 1.19 & 0.7 \\
& Clay (\%) & 17.7 & 20.2 & 15.45 & 5.20 \\
& pH & 5.04 & 3.44 & 6.05 & 5.57 \\
& CEC (me/100 g ) & 0.69 & 0.51 & 0.89 & 0.89 \\
& Organic carbon (\%) & 0.68 & 0.68 & 1.07 & 1.24 \\
& Clay (\%) & 9.20 & 11.7 & 13.95 & 8.20 \\
\hline
\end{tabular}

Total concentration of $\mathrm{Zn}, \mathrm{Cu}, \mathrm{Fe}, \mathrm{Mn}$ and $\mathrm{Pb}$ in soil was analyzed by digesting the soil with aqua rezia $(1: 10)$. Total concentration of the same metals in plant tissue was determined by digesting them by nitric acid followed by perchloric acid(12). In case of available $\mathrm{Zn}, \mathrm{Cu}$, Fe and $\mathrm{Mn}$ in soil $1 \mathrm{~N} \mathrm{HCl}$ was used as an extracting agent with a ratio of $1: 33^{(13)}$. Both total and available heavy metals were analyzed by AAS (Atomic Absorption Spectrophotometer). Results were statistically analyzed by using statistical software Stata version 12.

\section{Results and Discussion}

All elements became available at lower $\mathrm{pH}$ and among them availability of $\mathrm{Zn}$ and $\mathrm{Cu}$ correlated significantly with $\mathrm{pH}$ (Table 2). The parent material of sampling sites, selected for the research, is medium high land which suggested very low concentration of $\mathrm{CEC}^{(11)}$. Cation exchange capacity and clay provide more surface area for accommodation of the metal ions. Except $\mathrm{Zn}$ all metal ions availability was significantly related with CEC. Organic matter is another major accumulator of metals in soil. It has a unique character of making chelates with metals ${ }^{(10)}$. Results indicated its significant positive relationship between total concentrations of $\mathrm{Zn}$ and $\mathrm{Pb}$ and organic carbon (Table 3). On the other hand, available $\mathrm{Zn}$ and $\mathrm{Cu}$ were found to have significant positive relationship with organic carbon (Table 2). 
Most of the land was poor to very poor $(0.61-1.24 \%)$ in organic carbon (Table 1$)$. Amount of organic carbon increased with distance from the brick kilns (Table 1), which might be due to excessive temperature produced from brick manufacturing processes. This high temperature oxidizes organic carbon to carbon dioxide and carbon monoxide. As a result amount of organic matter was less in soils near brick kilns than the far areas. $\mathrm{pH}$ of the sampling sites also showed the same trend. It might be due to the deposition of sulfur dioxide produced from the brick kilns. Sulfur dioxide produces $\mathrm{H}_{2} \mathrm{SO}_{4}$ when it reacts with water. This acid might be responsible for lowering the $\mathrm{pH}$.

Table 2. Relationship between available heavy metal concentration and soil properties.

\begin{tabular}{lllll}
\hline & $\mathrm{pH}$ & OC & CEC & Clay \\
\hline $\mathrm{Zn}$ & $-0.2249^{*}$ & $0.5487^{* * *}$ & 0.0995 & 0.0812 \\
$\mathrm{Cu}$ & $-0.2945^{* * *}$ & $0.4666^{* * *}$ & $0.4958^{* * *}$ & $0.2490^{* *}$ \\
$\mathrm{Fe}$ & -0.0306 & 0.1220 & $0.2945^{* *}$ & $0.3177^{* * *}$ \\
$\mathrm{Mn}$ & -0.1029 & -0.0403 & $0.3397^{* * *}$ & 0.0683 \\
$\mathrm{~Pb}$ & -0.1242 & 0.1072 & $0.2137^{*}$ & 0.1575 \\
\hline
\end{tabular}

Table 3. Relationship between total heavy metal concentration and soil properties.

\begin{tabular}{lllll}
\hline & $\mathrm{pH}$ & $\mathrm{OC}$ & $\mathrm{CEC}$ & Clay \\
\hline $\mathrm{Zn}$ & 0.0170 & $0.5670^{* * *}$ & $0.4156^{* * *}$ & $0.2961^{* *}$ \\
$\mathrm{Cu}$ & $0.3772^{* * *}$ & 0.1827 & $0.4096^{* * *}$ & $0.2846^{* *}$ \\
$\mathrm{Fe}$ & $0.2890^{* *}$ & 0.0681 & $0.2799^{* *}$ & 0.1228 \\
$\mathrm{Mn}$ & 0.0501 & -0.0137 & 0.1358 & $0.2715^{*}$ \\
$\mathrm{~Pb}$ & $-0.2101^{*}$ & $0.2499^{* *}$ & $0.3688^{* *}$ & $0.549^{* * *}$ \\
\hline
\end{tabular}

$*, * *$ and ${ }^{* * *}$ indicate at 5,1 and $0.1 \%$ level of significance, respectively.

Accumulation of micronutrients in soil near brick kilns was depended on soil properties and among them fly ash was the most important one. Travel of particulate materials makes a very significant change in the soil that depends on wind speed, direction, humidity and season of the year. Accumulation of $\mathrm{Zn}$ and $\mathrm{Cu}$ was observed in soils within $1000 \mathrm{~m}$ and $\mathrm{Pb}, \mathrm{Fe}$ and $\mathrm{Mn}$ were found within $500 \mathrm{~m}$ distances from brick kilns (Fig. 1). This phenomenon makes the $500 \mathrm{~m}$ to $1000 \mathrm{~m}$ zone more vulnerable to heavy metal contamination. Results showed that soils in this area are already contaminated with $\mathrm{Pb}, \mathrm{Zn}$ and $\mathrm{Cu}$ and crossed maximum permissible limits ${ }^{(14)}$. Total $\mathrm{Pb}$, $\mathrm{Zn}$ and $\mathrm{Cu}$ range from 92.5 to 214,86 to 156 and 24.7 to $46.9 \mathrm{mg} / \mathrm{kg}$, respectively but Fe and Mn concentrations in soils of this area was within the critical limit. 


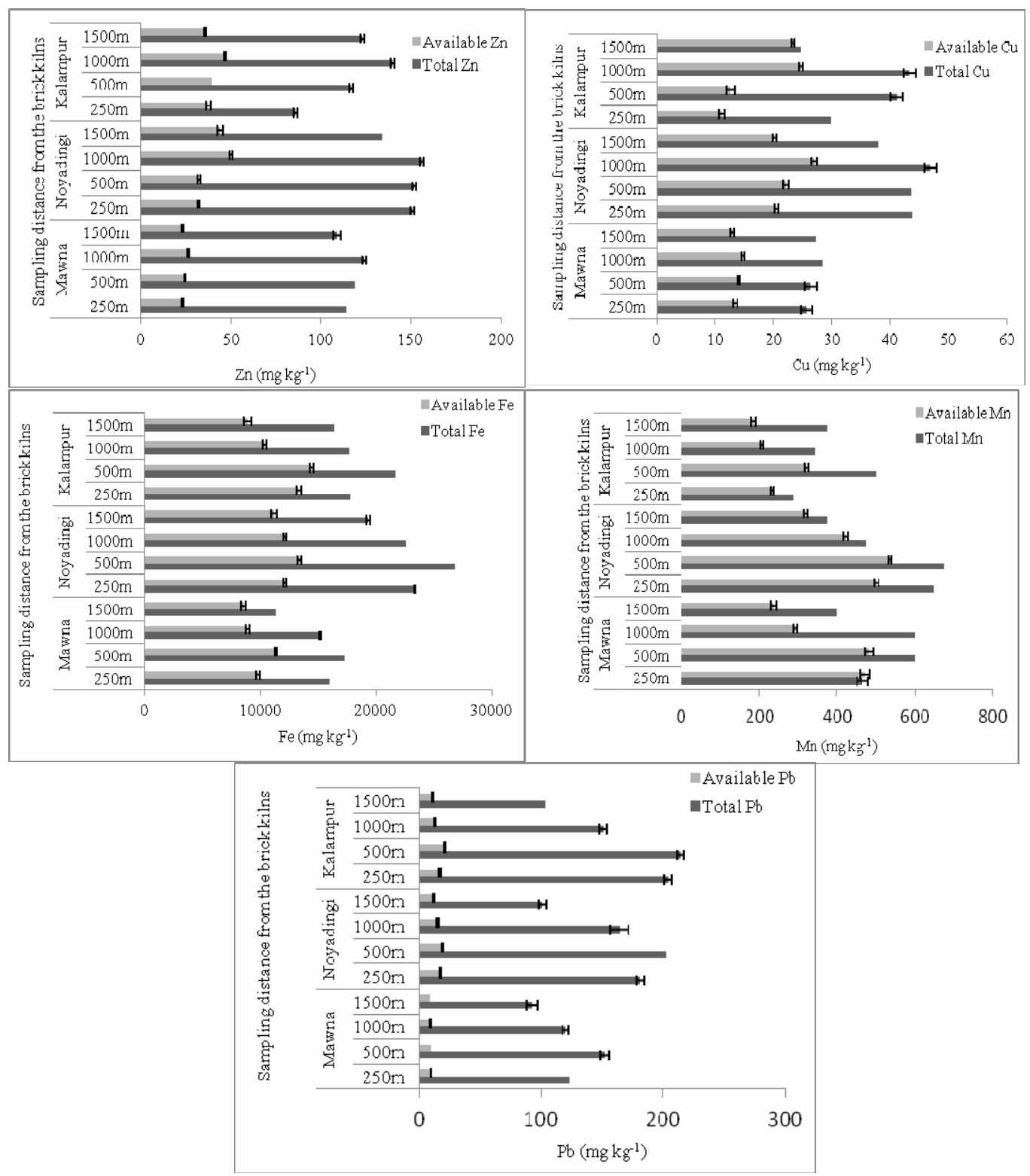

Fig. 1. Accumulation of total and available micronutrients and heavy metal in soils at different distances from brick kiln.

The concentrations of lead, iron and manganese were found highest in the $500 \mathrm{~m}$ soils whereas, $\mathrm{Zn}$ and $\mathrm{Cu}$ were within $1000 \mathrm{~m}$ distance from the brick kiln (Fig. 2), and these might be due to the dumping of fly ash in this zone. Fly ash or coal ash contains an appreciable amount of micronutrients( ${ }^{(6)}$. This trend was reduced with the distance 
because of the lower dumping of fly ash. In soils, Fe and Mn were within the critical limits but in plants they crossed the critical limits along with $\mathrm{Pb}, \mathrm{Zn}$ and $\mathrm{Cu}$. Accumulation of metals in plants in shorter distance from the brick kilns was noticed also might be due to the lower $\mathrm{pH}$. Heavy metal accumulation was reduced significantly with the distance (Fig. 2). The most alarming message is the accumulation of micronutrients was more than double in plants. The critical limits of $\mathrm{Pb}, \mathrm{Zn}, \mathrm{Cu}, \mathrm{Fe}$ and $\mathrm{Mn}$ are 2, 20, 6 , 100 and $25 \mathrm{mg} / \mathrm{kg}$, respectively ${ }^{(14)}$.

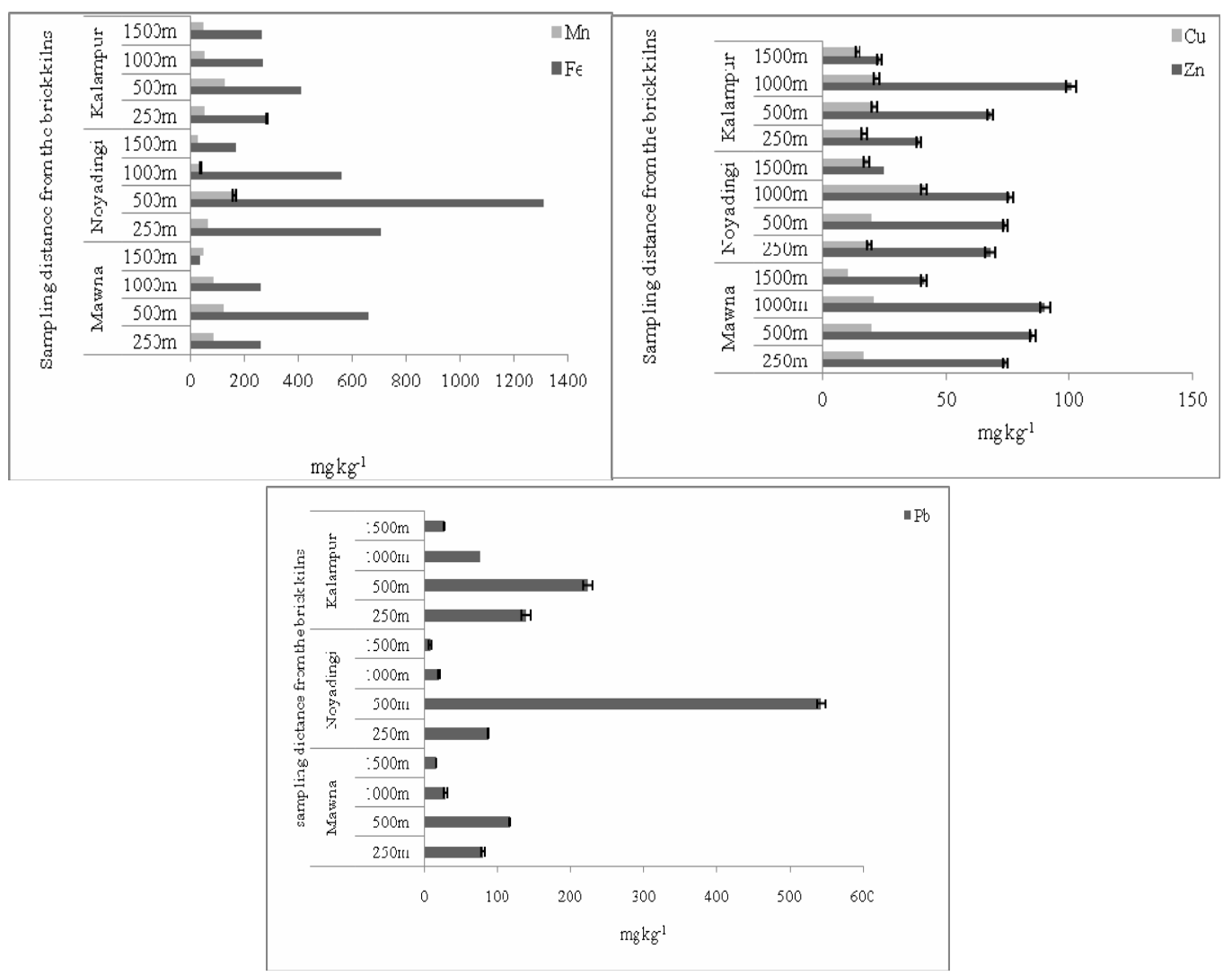

Fig. 2. Micronutrients and heavy metal uptake by plants at different distances from brick kiln.

The brick kilns were surrounded by fertile agricultural fields, far away from industry and more than $500 \mathrm{~m}$ away from highway. The parent material of the sampling sites was Young Brahmaputra and Jamuna floodplain, which has no evidence to accumulate such pollutants. On the other hand, surface soil has higher micronutrients and $\mathrm{Pb}$ concentrations than substratum soils, which indicates that contaminants were not originated from the groundwater. Accumulation of these contaminants also decreased with the distance from brick kilns. 
Results indicated that $\mathrm{Pb}, \mathrm{Zn}, \mathrm{Cu}$ were found at elevated level in both soil and plant. Iron and manganese crossed the critical limit in plants. In all the cases, 500 to $1000 \mathrm{~m}$ from brick kilns faces the maximum pollutants. The present experiment suggests that agriculture, grazing and any kind of farming should be avoided the zone of 500 to 1000 $\mathrm{m}$ from brick kilns as it faces the maximum heavy metal fall out.

\section{References}

1. Bangladesh Bureau of Statistics (BBS) 2012. Bangladesh population and housing census 2012. BBS, Govt. of Bangladesh. pp. 19.

2. Hossain M and AM Abdullah 2012. Securing the Environment: Potentiality of Green Brick in Bangladesh. J. Bangladesh University of Professional 1: 79-89.

3. Bayron RK 2009. Brick kilns going green. The Daily Star. December 13, 2009. pp. 5.

4. Ahmed S and I Hossain 2008. Applicability of air pollution modeling in a cluster of brickfields in Bangladesh. Chem. Eng. Res. Bul. 12: 28-34.

5. Alam GJ 2009. Environmental pollution of Bangladesh - It's effect and control. J. Pulp and Paper 51: 7-13.

6. Luo L, Y Ma, S Zhang, D Wei and YG Zhu 2009. Inventory of trace element inputs to agricultural soils. J. Environ. Man. 90: 2524-2530.

7. Harter RD 1983. Effect of soil pH on adsorption of lead, copper, zinc, and nickel. Soil Sci. Soc. Amer. J. 7: 47-51.

8. McBride MB 1994. Environmental Chemistry of Soils. Oxford Univ. Press, Oxford. pp. 406.

9. Bradl HB 2004. Adsorption of heavy metal ions on soils and soils constituents. J. Colloid. Interface Sci. 277: 1-18.

10. Johnson CE and RJ Petras 1998. Distribution of zinc and lead fractions within a forest Spodosol. Soil Sci. Soc. Amer. J. 62: 782-789.

11. BARC (Bangladesh Agricultural Research Council) 2005. Fertilizer Recommendation Guide. People's press and publication, Dhaka, Bangladesh. pp. 260.

12. Jackson ML 1962. Soil Chemical Analysis. Prentice-Hall Inc., Englewood Cliffs, NJ, USA. pp. 498.

13. Chowdhury MTA, L Nesa, MA Kashem and SM Imamul Huq 2010. Assessment of the phytoavailability of $\mathrm{Cd}, \mathrm{Pb}$ and $\mathrm{Zn}$ using various extraction procedures. Pedologist 53: 80-95.

14. Kabata-Pendias A 2004. Soil-plant transfer of trace elements - An environmental issue. Geodarma 122: 143-149. 